\title{
当科に护ける喉頭癌の臨床的検討
}

\author{
桑畑 直史 $\cdot$ 鹿野 真人 $\cdot$ 大谷旅
}

\section{Clinical Study of Laryngeal Cancer}

Naofumi Kuwahata, Makoto Kano and Iwao Ohtani

(Fukushima Medical College)

\begin{abstract}
We reviewed 143 patients with laryngeal cancer, who had undergone primary treatment in our hospital between 1983 to 1993 . These patients consisted of 45 cases of supraglottic carcinoma, 94 cases of glottic carcinoma and 4 subglottic carcinoma. The respective five-year survival rates were $55.4 \%, 80.1 \%, 100 \%$ and $72.9 \%$ for supraglottic carcinoma, glottic carcinoma, subglottic carcinoma and that over all. Successful radiation control rates for primary glottic carcinoma in stage I and stage II were $89.4 \%$ and $76.9 \%$, respectively. Laryngectomy was performed on 65 patients, but the larynx could be preserved in $54.5 \%$ of all cases.
\end{abstract}

Key words : clinical study, laryngeal cancer, survival rate

\section{はじめに}

喉頭癌は耳鼻咽喉科領域の中で発生頻度の高い悪性腫 瘍の一つであり，その治療法については古くょり検討さ れている. 近年では早期症例が増加し, また治療法の進 歩により高い生存率が得られるようになってきた. 我々 はその病態を把握し治療方針の再検討を行うことを目的 とし, 最近11年間に当科で一次治療を行った啹頭癌症例 について統計的観察を行い, 若干の文献的考察を加兄報 告する.

\section{対 象}

1983年 1 月より1993年12月むでの11年間に当科で一次 治療を行った喉頭癌患者170例のらち追跡調査可能であ った143例を対象とし，その治療成績を検討した。

1 ）性別・年齢分布

\section{結 果}

143例中男性は133例，女性は10例で，男女比は $13: 1$ であった．初診時年龃は44歳から88歳にわたり，60歳台 が56人と最も多く，50歳台から70歳台が全体の $89 \%$ を占
め, 平均は64.7歳であった(図 1 ).

2 ) 原発部位

143例中, 声門癌が94例 $(65.7 \%)$ と最も多く, 次いで 声門上癌45例(31.5\%), 声門下癌 4 例 (2.8\%)であった.

3 ) 病理組織学的診断

141例が扁平上皮癌であり，このらち分化型について

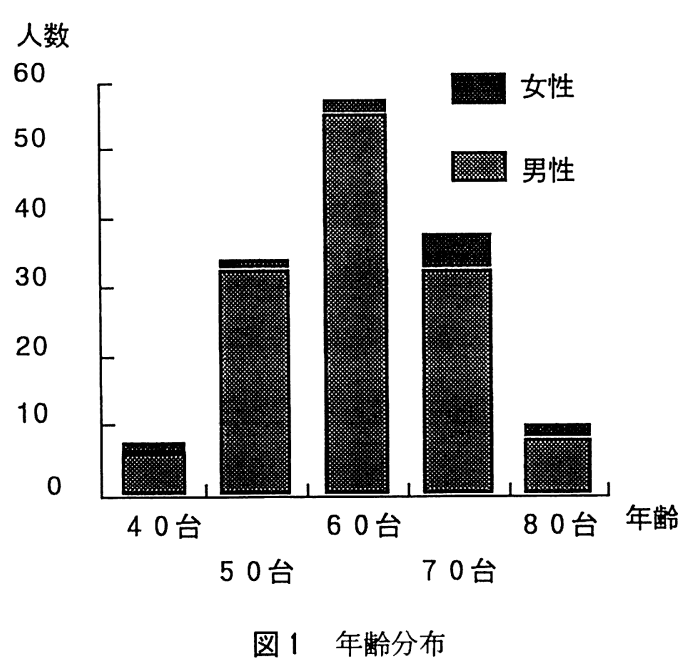


確認できた101例の内訳は，高分化型が42例(41.5\%)， 中分化型44例(43.6\%)，低分化型14例(13.9\%) 拈よび末 分化型 1 例 (1.0\%) で，高分化・中分化型が全体の $85 \%$ を占めていた．また腺扁平上皮癌と平滑筋肉腫がそれぞ れ 1 例認められた。

\section{4 ) 病期分類}

UICC 分類(1987)を用いて病期分類を行った.

TNM 分類では全例で T1 : 67 例, T2 : 34 例, T3 : 30 例, T4: 12 例であり, また N0：121 例, N1 : 13 例, $\mathrm{N} 2 ： 7$ 例, N3：2 例で, 初診時の頸部リンパ節転移は 22例(15.4\%)に，遠隔転移は 1 例に認められた（表 1 ）. 原発部位別にみると声門上癌45例では T1・T2 あわせ て21例(46.7\%)であり，頸部転移陽性例は18例(40.0\%) であった(表 2 )。声門癌94例では T1・T2 あわせて77 例 (81.9\%) を占め, 頸部転移陽性例は 4 例 (4.3\%)であ った(表 3 ). また声門下癌 4 例では $\mathrm{T} 1$ ・T2 おわせて 3 例 (75.0\%)で，頸部転移は認めなかった（表 4 ).

全例の病期分類は I 期66例 (46.2\%)， II 期28例 (19.6 $\%) ， \mathrm{III}$ 期30例 (21.0\%)， $\mathrm{N}$ 期19例 (13.2\%)であった.

表 1 喉頭癌全症例の TN 分類

\begin{tabular}{r|r|r|r|r||r}
\hline & N 0 & N 1 & N 2 & N 3 & 合計 \\
\hline T 1 & 66 & 0 & 1 & 0 & 67 \\
\hline T 2 & 28 & 4 & 2 & 0 & 34 \\
\hline T 3 & 20 & 6 & 4 & 0 & 30 \\
\hline T 4 & 7 & 3 & 0 & 2 & 12 \\
\hline \hline 合計 & 121 & 13 & 7 & 2 & 143
\end{tabular}

表 2 声門上癌の $\mathrm{TN}$ 分類

\begin{tabular}{r|r|r|r|r||r}
\hline & N 0 & N 1 & N 2 & N 3 & 合計 \\
\hline T 1 & 6 & 0 & 1 & 0 & 7 \\
\hline T 2 & 8 & 4 & 2 & 0 & 14 \\
\hline T 3 & 10 & 4 & 2 & 0 & 16 \\
\hline T 4 & 3 & 3 & 0 & 2 & 8 \\
\hline \hline 合計 & 27 & 11 & 5 & 2 & 45
\end{tabular}

表 3 声門癌の TN 分類

\begin{tabular}{r|r|r|r|r||r}
\hline & N 0 & N 1 & N 2 & N 3 & 合計 \\
\hline T 1 & 58 & 0 & 0 & 0 & 58 \\
\hline T 2 & 19 & 0 & 0 & 0 & 19 \\
\hline T 3 & 10 & 2 & 2 & 0 & 14 \\
\hline T 4 & 3 & 0 & 0 & 0 & 3 \\
\hline \hline 合計 & 90 & 2 & 2 & 0 & 94
\end{tabular}

表 4 声門下癌の $\mathrm{TN}$ 分類

\begin{tabular}{r|r|r|r|r||r}
\hline & N 0 & N 1 & N 2 & N 3 & 合計 \\
\hline T 1 & 2 & 0 & 0 & 0 & 2 \\
\hline T 2 & 1 & 0 & 0 & 0 & 1 \\
\hline T 3 & 0 & 0 & 0 & 0 & 0 \\
\hline T 4 & 1 & 0 & 0 & 0 & 1 \\
\hline \hline 合計 & 4 & 0 & 0 & 0 & 4
\end{tabular}

声門上癌45例の らち I 期が 6 例， II 期が 8 例で，早期症 例は14例(31.1\%)にすぎなかった。 これに対し声門癌94 例では I 期は58例，II期は19例で， I + II 期の早期症例 が77例(81.9\%)を占めていた（表 5 ).

5 ）治療成績

カプラン・マイヤー法による喉頭癌全体の 5 年生存率 は72.9\%で，病期別では I 期 $82.4 \% ，$ II 期 $82.4 \%$ ， III期 $64.2 \% ， \mathrm{~N}$ 期 $45.6 \%$ であった（図 2 ）。また部位別にみる

表 5 原発部位別頻度扣よび病期分類

\begin{tabular}{r|r||r|r|r}
\hline & \multicolumn{1}{|c||}{ 合計 } & 声門上 & \multicolumn{1}{c|}{ 声門 } & \multicolumn{1}{|l}{ 声門下 } \\
\hline I 期 & 66 & 6 & 58 & 2 \\
\hline II 期 & 28 & 8 & 19 & 1 \\
\hline III 期 & 30 & 18 & 12 & 0 \\
\hline IV 期 & 199 & 13 & 5 & 1 \\
\hline 合計 & 143 & 45 & 94 & 4
\end{tabular}




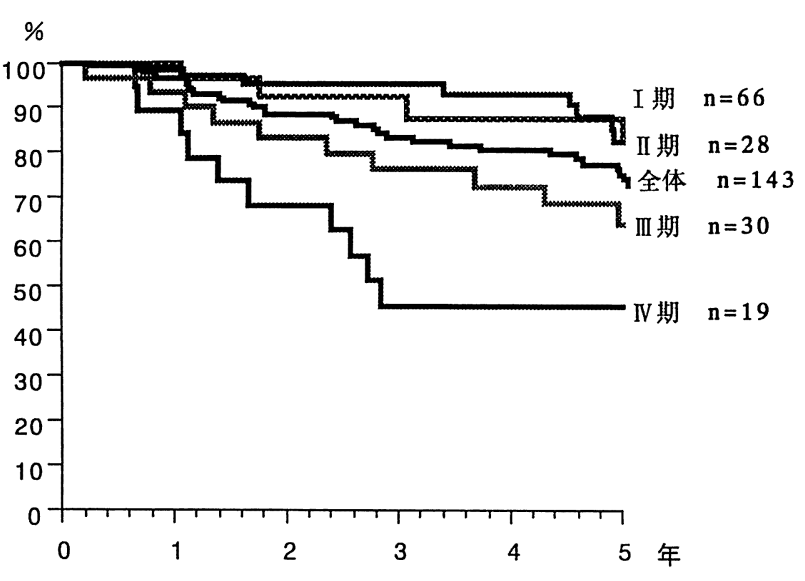

図 2 病期別 累積 5 年生存率曲線

と, 声門上癌 $55.4 \%$, 声門癌 $80.1 \%$, 声門下癌 $100 \%$ で あり (図 3 ), それぞれの病期別の 5 年生存率は, 声門上 癌が I 期 $66.7 \%$ ，II期 $71.4 \% ，$ III期 $59.1 \%, \mathrm{~N}$ 期 $30.8 \%$ であり，声門癌では I 期 $82.9 \% ，$ II 期 $86.8 \% ，$ III 期 58.3 \%， N期 $53.3 \%$ であった．また初回治療による全症例の 喉頭保存率は $58.7 \%$ で，5年間の経過中に救済手術を含 めて65例に喉頭全摘が行われ，5年経過時点での喉頭保 存率は $54.5 \%$ であった。な技部分切除については喉頭は 保存されたものとした.

6 ）治療経過

声門上癌：I 期は 6 例あり, 根治照射例と喉頭全摘例 はそれぞれ 3 例であった。根治照射例の 3 例中 1 例は局 所再発のため喉頭全摘が行われ，局所は制御されたが初 回治療より 5 年後に遠隔転移死した。喉頭全摘 3 例には

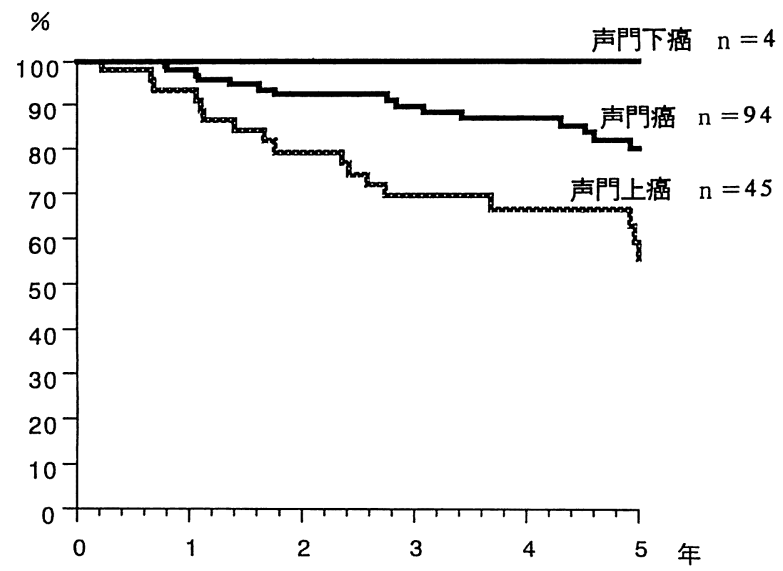

図 3 原発部位別 累積 5 年生存率曲線
再発を認めなかった．II期は 8 例めり，根治照射 3 例と 喉頭全摘 5 例であった．根治照射例の 3 例のらち 1 例に 領域リンパ節転移を認めたが，高齢のため救済手術が行 えず腫瘍死した．喉頭全摘が行われた 5 例では， 1 例が 頸部転移・気管孔再発を繰り返し，救済手術を行ったが 5 年後に腫瘍死した． III期の18例では全例に啹頭全摘が 行われた。このらち2 例(11.1\%)に再発を認め, 救済手 術にて局所および頸部は制御されたが， 1 例は肺転移に て死亡した． $\mathbb{N}$ 期は13例あり，9例に喉頭全摘が行われ たが，4例は手術拒否や合併症のため放射線療法と化学 療法による保存的治療が行われた．喉頭全摘例には再発 を認めなかった．保存的治療が行われた 4 例のうち 3 例 は死亡し，その経過は平均 12 力であった．全声門上癌 45 例では14例 (31\%)に再発を認め, 局所再発の及 2 例 (4.4\%), 頸部再発の及 5 例 $(11.1 \%)$, 局所+頸部再発 5 例 (11.1\%), 局所再発+遠隔転移 1 例 (2.2\%) 拉よび 頸部再発十遠隔転移 1 例 $(2.2 \%)$ であった。声門上癌の 5 年間の喉頭保存率は $20 \%$ であった。

声門癌：I 期は58例あり, 根治照射例が49例, レーザー 手術が 8 例, 喉頭全摘が 1 例に行われた. 根治照射 49 例 のらち42例には再発を認めず，放射線による局所制御率 は $85.7 \%$ であった.レーザー手術 8 例のらち 2 例に再発 を認め， 1 例は局所再発のため部分切除にて制御され， 1 例は肺転移のため死亡している. 根治照射後の救済手 術は 5 例に行われ，4 例が救済されたが，1 例は喉頭全 摘後に領域リンパ節転移死している．II期は19例で根治 照射が14例，喉頭全摘が 5 例 (26.3\%) に行われた．根治

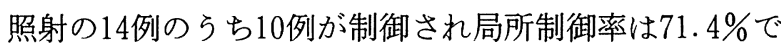
あった. 1 例は放射線の効果を認めず部分切除が行われ， また再発した 3 例のうち喉頭全摘が行われた 2 例は生存 している. 喉頭全摘 5 例には再発は認められなかった。 III期は 12 例で放射線治療による保存的治療例が 1 例に 喉頭全摘が11例に行われた。保存的治療の 1 例は原発巣 死した。喉頭全摘11例では 9 例 $(81.8 \%)$ に再発はなく, 再発した 2 例のらち 1 例は救済手術により制御されてい る. $\mathrm{N}$ 期は 5 例あり, 保存的治療が 1 例, 喉頭全摘が 4 例に行われた。保存的治療が行われた 1 例は原発巣死し ている. 喉頭全摘の 4 例のらち 1 例に頸部転移を認めた が頸部郭清術にて救済されている. 全声門癌94例では16 例 $(17.0 \%)$ に再発を認め, 局所再発のみ 8 例 $(8.5 \%)$, 頸部再発の及 5 例 (5.3\%), 局所十頸部再発 2 例 $(2.1 \%$ ) および頸部再発＋遠隔転移 1 例(1.1\%)であった。声門 
癌の 5 年間の喉頭保存率は $72.3 \%$ であった。

声門下癌：I 期の 2 例には放射線治療が行われ， 1 例 に局所再発を認めたが喉頭全摘にて制御されている，II 期および $\mathbb{N}$ 期の各 1 例は喉頭全摘にて治癒している. 全 声門下癌 4 例の 5 年間の喉頭保存率は $25.0 \%$ であった.

7 ) 死因・多重癌

5 年間に死亡の確認された症例は 143 例中 31 例で, 腫 瘍死が15例と他因死16例であった. 腫瘍死では, 原発巣 死 5 例, 領域リンパ節死 8 例で, 遠隔転移死は肺転移に よる 2 例であった．領域リンパ節死の 8 例は声門上癌が 6 例と声門癌が 2 例であった。他因子の内訳は他癌死 8 例, 老齢の心肺血管疾患が 7 例で, 1 例は喉頭全摘例で 喀痰をつまらせて窒息死した症例があった．本統計143 例のうち1994年12月の時点で, 17例に多重癌を認め, こ のらち三重癌を 2 例に認めた。 多重癌の発生部位は胃 5 例, 膀胱 3 例, 肺 3 例, 肝㵴 2 例などで, 三重癌は胃癌 十膀脱癌, 胃癌十鼻腔腺癌との合併であった.

\section{考察}

喉頭癌は耳鼻咽喉科・頭頸部外科領域に执いて最も頻 度の高い悪性腫瘍の一つである. 本邦での喉頭癌の男女 比は 11〜12:1 との報告が多く122), 本統計でも $13: 1$ であった．初診時年龄についても諸家の報告1) 4) と同様 で60歳台が最も多かった。病理組織学的診断については 太田ら 2) や木俣ら ${ }^{3)}$ と同様にほぼ全例が扁平上皮癌であ った. 原発部位別頻度も日本 TNM 分類委員会の研究 資料5) やその他の報告26) では声門上癌と声門癌の比率

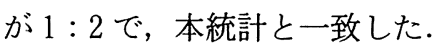

病期分類では声門癌に占める早期癌の割合は76～79\% であるのに対し，声門上癌に占める進行癌の割合は53 64\%とされている.さらに声門癌と声門上癌の頸部転移 陽性例はそれぞれ7.6〜 $10.7 \%$ と 42～48\% と報告されて (る1226)。本統計に打いても，声門癌は早期癌が多く， 頸部転移陽性例も $4.3 \%$ と特に少なかったが，声門上癌 では原発巣も進行した症例が多く, 早期より頸部リンパ 節転移をきたして括り，喉頭癌の原発部位による病態に 明らかな差が認められた。

喉頭癌全体の 5 年累積生存率は70 80\% と報告1) 4) d れ，我々の72.9\%はこれらに劣るものではない，これを 病期別にみると，I 期が $82.4 \%$ と満足のできるものでは なかったが， III期・ $\mathbb{N}$ 期については64.2\%・45.6\%と他 施設に比べて遜色はなかった。これは声門癌 I 期で 6 例
が他病死しているためと考えられた.

ところで喉頭癌の治療成績は一般に比較的良好である が，喉頭全摘例では失声をきたしQOL の著しい低下を もたらす。このため現在では腫瘍の制御と同時に，音声 機能の温存や再建が重要視されてきた. その指標として 喉頭保存率があるが，浦野ら1) は初回治療における喉頭 保存率を $65.4 \%$, 太田ら 2) と吉積ら ${ }^{6)}$ は初回治療に扣け る喉頭保存率と救済手術を含めた喉頭保存率をそれぞれ $66.6 \%$ と $61 \% ， 64.9 \%$ と $57.8 \%$ と報告している. 当科で は $58.7 \%$ と $54.5 \%$ と若干低いものとなった。この原因は 初回治療の際に声門上癌 $\mathrm{T} 1$ に対して 3 例, T2 症例に 対して 4 例, 声門癌 $\mathrm{T} 1$ およよ゙゙ $\mathrm{T} 2$ 症例でも 6 例に放射 線療法上り喉頭全摘が優先された事によっている.

声門癌 T1・T2 亿対する放射線治療の局所制御率は 太田ら ${ }^{2)}$ は $86.4 \% \cdot 81.8 \%$ ，平川ら ${ }^{4)}$ は84.7\%・82.9\% と報告している。本統計では T1 で85.7\%，T2 で71.4 \%と，T1については他報告と比べても比較的良好であ るが，T2でやや低かった．現在は $\mathrm{T} 1$ および $\mathrm{T} 2$ に対 しては，放射線療法を第一選択として喉頭保存率の向上 を図っている，喉頭保存率の向上には局所制御率の一層 の改善が求められるが，不破ら7) は腫瘍形態が浸潤型ま たは腫瘍の範囲が声帯の $2 / 3$ 以上を占めるものは放射線 療法に抵抗する危険群であるとして根治照射に続きレー ザーサーミアの併用を行っている．また吉野ら ${ }^{8)}$ は早期 声門癌に㨟いて腫瘍発育形式が潰瘍型や verrucous carcinomaなどは放射線感受性がそしいため初回治療で部 分切除を選択し局所制御を改善している. 再発の危険群 に対する初回治療の検討も今後の課題としたい。

腫瘍死15例の内訳をみると, 原発巣死 5 例, 領域リン 录節死 8 例および遠隔転移死 2 例で，局所および頸部転 移の制御に難渋していた．鈴木ら ${ }^{9}$ は喉頭全摘十頸部郭 清術を行った声門上癌32例の検討で59.4\%に頸部リンパ 節転移を認め，また術前 $\mathrm{N} 0$ 症例の $33.3 \%$ にN $(+)$ が あり積極的頸部郭清術の必要性を示唆している. 本統計 でも領域リンパ節死 8 例のうち 6 例は声門上癌が占め, 初回に頸部郭清術を行わなかった T2N0の 1 例は再発 時に頸部郭清術を行ったが傍気管リンパ節転移を救済出 来なかった。また $\mathrm{N} 2$ 症例 3 例は初回に両頸部郭清術を 行ったが，頸部再発をきたし，救済出来なかった．声門 上癌に対する頸部郭清の適応も今後検討されるべきと思 われた。

一般に喉頭癌は他癌に比べて多重癌の頻度が高く, 同 
時性・異時性のものも含め $5 \sim 10 \%$ と報告されてい る34). 本統計に扰いても1994年12月の時点で多重癌は 17例(11.9\%)に認められ，このらち三重癌が 2 例あり, 143例中19癌が確認された。一般に肺や胃・食道などの 消化管に多いとされているが, 膀胼癌 3 例, 肝癌 2 例な どにも発生した。消化管をはじめ全身の定期的なスク リーニングが必要と思われた。

\section{まとめ}

1. 1983年 1 月より1993年12月までの11年間に, 当科 で一次治療を行った喉頭癌症例のうち, 追跡可能であっ た143例について統計的観察を行った.

2. 喉頭癌全例の 5 年累積生存率は $72.9 \%$ であった。 原発部位別にみると，声門上癌が I 期 $66.7 \% ，$ II 期 71.4 $\%, \mathrm{III}$ 期 $59.1 \%, \mathrm{~N}$ 期 $30.8 \%$ であり, 声門癌では $\mathrm{I}$ 期 82.9 $\%$ ，II期 $86.8 \% ，$ III 期 $58.3 \% ， \mathrm{~N}$ 期 $53.3 \%$ であった.

3. 全例について初回治療に拈ける喉頭保存率は58.7 $\%, 5$ 年経過時点での喉頭保存率は $54.5 \%$ であった.

4. 今後の治療成績向上のためには, 根治照射による 局所制御の改善とともに, 声門上癌に対する予防的頸部 郭清術の適応を考慮し，また再発の早期発見に努めるこ とが重要と思われた。

5 . 多重癌を 143 例中 17 例 (11.9\%) 亿認め, 定期的な 全身の検診が必要と思われた.

\section{引用文献}

1 ) 浦野 誠, 岩田重信, 高須昭彦, 他 : 当教室に批多喉頭 癌の統計的観察. 耳鼻臨床 補65：127 132, 1993.

2) 太田行紀, 平川勝洋, 夜陣紘治, 他 : 喉頭癌の臨床的検討. 耳鼻臨床 補 $27: 21 \sim 30,1994$.

3 ）木俣清子, 加藤一壽, 白木直也, 他 : 当科に批子喉頭癌 の統計的観察. 耳鼻臨床 補73 : 126 131, 1994.

4 ) 平川勝洋, 夜陣紘治, 田頭宣治, 他 : 喉頭癌の臨床的統計. 耳鼻臨床 補27：199 206, 1988.

5 ）日本 TNM 分類委員会, 頭頸部小委員会: 頭頸部 TNM 分 類研究資料. 33 50頁, 国立がんセンター頭頸科, 東京, 1988.

6）吉積 隆, 宇留間哲也, 佐竹文介, 他: 群馬県立がんセン ターに打ける䐅頭癌 20 年の治療成績. 日癌治 $28: 1873 \sim$ 1879, 1993.

7 ) 不破信和, 森田晧三, 加藤恵利子, 他:喉頭ファイバー所 見よりみた $\mathrm{T} 1$ 声帯癌の放射線治療後の局所再発例の検討. 日癌治 $29: 577 \sim 581,1994$.

8）吉野邦俊, 佐藤武男 : 㗋頭早期癌の治療上の問題点. 日癌 治 $26: 691 \sim 692,1994$.

9 ) 鈴木 隆, 岩田重信, 高須昭彦, 他: 声門上癌に㧊ける頸 部リンパ節転移の検討. 耳鼻臨床 補65：141〜148, 1993.

$$
\left(\begin{array}{l}
\text { 別刷請求先 : 桑畑直史 } \\
\mathbf{T} 960-12 \text { 福島市光が丘 } 1 \\
\text { 福島県立医科大学耳鼻咽喉科学教室 }
\end{array}\right)
$$

